\title{
What Cost and Usage Data Reveals About E-Book Acquisitions Ramifications for Collection Development
}

\section{Steven B. Carrico, Tara T. Cataldo, Cecilia Botero, and Trey Shelton}

To better determine how e-book acquisitions might affect future collection development decisions, a team of librarians from the University of Florida (UF) launched a project to assess cost and usage of e-books purchased using three different acquisitions methods: e-books acquired in large publisher packages; single-title e-books selected through firm orders; and e-books purchased through two patron-driven acquisitions (PDA) plans. The cost-usage data were then sorted into three broad areas of subject disciplines-humanities and social sciences (HSS); science-technology-engineering-mathematics (STEM); and medicine (MED)—and the results were reviewed and summarized. The authors compared the cost-usage data of e-books acquired by the acquisitions methods across the three subject areas and describe how the findings are affecting current and future acquisitions, traditional collection management, and budgeting at UF.

$\mathrm{T}$ he Smathers Libraries has a primary mission to support the wide-ranging research and instructional activities at the University of Florida (UF), a large land-grant university with an annual enrollment of more than 49,000 and employing more than 3,000 faculty. ${ }^{1}$ The university also has more than one hundred undergraduate and two hundred graduate degree programs based in sixteen colleges that entail dozens of subject disciplines. ${ }^{2}$ With such a large scope of departments and degree programs to support across the sciences, humanities, social sciences, and medical-health related fields, the Smathers Libraries are challenged to meet the needs of this vast and diversified clientele. Moreover, the state is emphasizing distance-learning initiatives, with the libraries expected to develop and boost online resources to serve these new constituents.

Within this landscape, a team of librarians from the Smathers Libraries (two from the acquisitions department, one from the Marston Science Library, and one from the Health Science Center Libraries) began a project to assess the number, cost, and use of e-books acquired for perpetual ownership by the libraries. The importance of determining the cost and usage of e-books purchased to support multiple subject disciplines is paramount as the Smathers Libraries face restrictive annual materials funding. A primary goal of the project was that the Libraries might apply the findings to improve the method of allocating e-book budgets. 
The team focused on three purchase methods: (1) e-books acquired through large publisher packages; (2) e-books acquired through firm ordering, which includes selection of e-books from the primary approval/slip plan; and (3) e-books acquired through patron-driven acquisitions (PDA) plans. The team was especially interested in determining the cost effectiveness of purchases in different disciplines, accomplished by sorting the e-books using Library of Congress Classification (LCC) across broad subject areas.

The team posed three questions to serve as the project's guiding objectives:

1. How does cost-use of e-books purchased in packages, selected using firm orders, and acquired by PDA compare with regard to the methods of acquisitions?

2. How does the cost-use of e-books as acquired using the three main acquisitions methods compare when sorted by three broad subject areas-humanities and social sciences (HSS); science, technology, engineering, and mathematics (STEM); and medicine (MED), which includes related health and physiology disciplines?

3. How will this study of cost-use analysis of e-books at UF affect collection development, particularly future e-book initiatives and budget allocation?

\section{Literature Review}

A plethora of research on e-book acquisition methods, usage studies, and collection management has been published. This review of the literature highlights research that the authors deem most relevant to the analyses described in this paper. PDA, also known as demand-driven acquisitions (DDA), is an increasingly popular method for acquiring e-books in academic libraries. For many college and library administrators battling stringent materials budgets, PDAs are becoming mainstays for e-book collection building. Several recent articles and books have been published on the PDA/DDA model. Herrera shares experiences of developing and running a PDA at the University of Mississippi. ${ }^{3}$ Nixon, Freeman, and Ward's Patron-Driven Acquisitions: Current Successes and Future Directions and Swords' Patron-Driven Acquisitions: History and Best Practices were published in 2011 and contain chapters examining the historical, current, and future permutations of the PDA model. ${ }^{4}$ Shepherd and Langston share the planning, processes, implications, and future of shared, consortial PDA plans at the California State University system. ${ }^{5}$ Shepherd and Langston's finding that "in general, the number of books purchased in each subject was proportional to the number of books represented by that subject in the entire collection" should inform librarians establishing PDA profiles and would most likely also apply to other parameters of the profile. ${ }^{6}$

Anderson et al. and Bracke, Hérubel, and Ward offer insightful overviews on the books received through PDAs using their libraries' interlibrary loan (ILL) programs. ${ }^{7}$ Although both articles focus on print, not e-books, the studies conducted analyze the college and subject areas of the faculty or students requesting the books via ILL. A team of librarians from the University of Illinois at UrbanaChampaign (UIUC) and Penn State libraries did a study on print monographs purchased on approval at the two ARL libraries, performing in-depth analyses on costs, usage, and coverage across subject disciplines, similar in approach to the study described in this paper. Research conducted during the period July 1, 2004-March 31, 2007 at the two institutions showed approval books had an average cost per use of $\$ 19.83$ at Penn State and $\$ 22.28$ at UIUC; more significantly, circulation data revealed 31 percent of approval books at Penn State and 40 percent of approval books at UIUC did not circulate approximately two to three years after purchase. ${ }^{8}$ Hinken and McElroy discuss the implications of e-books purchased through consortial PDAs. ${ }^{9}$ An interesting 2010 analysis was conducted by Reynolds et al. of the user-driven acquisitions program at Texas $\mathrm{A} \& \mathrm{M}$ University Library demonstrated many advantages of the use-driven acquisitions model related to user satisfaction, librarian perception, budgeting and accounting, and return on investment. ${ }^{10}$ The Texas A\&M study utilized a "suggest a purchase" form that students, faculty, and staff could use to request monographs or media resources in any format. The Texas A\&M study showed that 78 percent of materials purchased from the "suggest a purchase" form were used, with 40 percent of the titles being used more than once.

Sharp and Thompson's case studies considered the various e-book purchasing models, comparing PDA and title by title purchasing. ${ }^{11}$ Shen et al. compared e-book purchases triggered through a PDA program to hypothetical librarian selections and discovered that "patron selections closely resemble librarian selections in terms of content level and recommended use." 12 Yet, despite the widespread adoption of PDAs in academic libraries, there are few published studies that demonstrate how these e-book programs are boosting collection building and user support across subject disciplines. Nor has there been much published on how academic libraries are integrating PDAs into traditional collection management policies.

Sprague and Hunter analyzed their library's e-book holdings and usage with three major e-book aggregators using LCC to determine which subject areas each title supported. ${ }^{13}$ Further studies compare e-book usage across subject disciplines. Hoseth and McLure discuss e-book usage in the social sciences. ${ }^{14}$ McLure and Hoseth analyzed e-book usage from an e-book library PDA plan using broad 
subject categories, and found that business, education, engineering, fine arts, and science seemingly garner the most usage. ${ }^{15}$ Pomerantz investigated the e-book content made available to users in the nursing and business subject disciplines. ${ }^{16}$

Other studies focus on the effect of e-books acquisitions methods on usage patterns. Lamothe compared e-book usage from individual title purchases and packages in both NetLibrary and Ingram's MyiLibrary, along with Springer packages ${ }^{17}$ According to Lamothe, 66 percent of individually purchased books in NetLibrary were used compared to only 29 percent of the NetLibrary packages. With MyiLibrary, 72 percent of the individually purchases titles were used compared to 6 percent of package titles. An analysis of usage in Springer packages showed 32 percent of this collection was used. Individually purchased titles received greater usage, followed by the publisher package, and the lowest use was with the aggregator packages. Roncevic suggested that availability of usage reports is a key factor to consider before purchasing e-books on a particular platform. ${ }^{18}$ Lannon and McKinnon analyzed usage patterns of business and economics e-book collections at McGill University from NetLibrary, SpringerLink, and Ebrary. ${ }^{19}$ The authors at least partially proved their hypothesis that the majority of usage resulted from a small percentage of the title purchased was true. The authors also speculated that concurrent user limits and the method of selection (approval plans, firm orders for course reserves, and packages) may have influenced the usage for the various e-book collections. Lannon and McKinnon concluded that their analysis supported the purchase of e-books through approval-plan and PDA models, but questioned the sustainability of purchasing e-books in packages; however, as the authors did not include a cost-per-use analysis in their report, it does not seem entirely reasonable to question this acquisition method, which is based on usage alone. Studies on the acquisitions of e-books through packages are available in the literature.

Tucker conducted a case study analysis of the usage of two e-book collections offered, NetLibrary and ebrary, and reviewed trends in publishing, including breakdowns in specific areas of subject disciplines. ${ }^{20}$ Use of NetLibrary e-books was highest in the liberal arts and health sciences, while ebrary's e-books received the highest use in the urban affairs, health sciences, hotel, and fine arts collections. Five publishers were in the top ten publishers of both packages. In contrast to Lannon and McKinnon's findings, Tucker discovered e-books in the business subject areas received lower usage compared to other subject areas. This finding may be because of the acquisition methods employed and the number of students enrolled in business programs at each institution. An important factor in Tucker's study was that because the "study is analyzing the percentage of titles used," it did not take into account titles used more than once. ${ }^{21}$

\section{E-Book Acquisitions at UF}

The Smathers Libraries have acquired e-books since the mid-1990s and currently have collective access to 899,296 e-books. ${ }^{22}$ For the greater part of two decades, the majority of e-books offered to UF users were either purchased in large publisher packages (e.g., SpringerLink collections) or maintained through subscriptions to collections of various sizes (e.g., Books $24 \mathrm{X} 7$ ), but seldom through individual firm or approval orders. Few firm order requests were placed for e-books as many selectors reported UF faculty and users voiced displeasure with e-book usability and navigation, in addition to mutual complaints about the lack of researchlevel published content available in e-book versions.

Fueling this reluctance to place firm orders for e-books was a sustained series of flat or reduced material budgets experienced by the Smathers Libraries. Annual book budgets not only became increasingly restrictive, but the cost of e-resources were escalating, resulting in depletion of print serial and book funds to pay for online resources. Economically, it made good sense for selectors to support e-book acquisitions through annual subscriptions and large package purchases paid for by a central or auxiliary fund and not from their own monograph budgets. From an operations standpoint, subscribing to or purchasing large packages containing dozens or hundreds of e-book titles requires only one license agreement, and one invoice was advantageous. Firm ordering the same number of e-books requires considerably more overhead in the selection and ordering processes, thus acquisitions, especially for the larger packages, is a far more efficient method for staff and selectors. Not only are e-book packages faster and easier to acquire, the acquisitions of e-books packages often contain content in specific subject collections, such as business or sociology. Purchasing publisher packages is a highly efficient method for acquiring e-books that can target broad or specific subject disciplines.

As e-book aggregators and publishers improved platform functionality, and as academic publishers and university presses offered more of their content faster as e-books, e-book use increased at UF. The convenience of accessing e-books from laptops and offices also was an important contributing factor in the growth of e-book use. The spike in e-book use impelled selectors to place more individual firm orders for e-books, but firm order selection at the Smathers Libraries spiked after the large library book vendorsCoutts, Blackwell's, and YBP-began to offer e-books in their online databases. The vendor databases made e-book browsing, review of content, and ordering quick and convenient; and, not surprisingly, selectors at the Smathers Libraries responded by placing more orders for e-books. Now, even with depressed book budgets, selectors, especially in the sciences, frequently choose an e-book version over a 
print counterpart, resulting in a substantial increase in the number of e-books purchased using firm orders.

Besides obtaining e-books through packages or individual firm orders, a third and relatively recent acquisitions method for UF is PDA. The two PDA projects used in this study were developed with Coutts, hosted on their MyiLibrary e-book platform, and offered e-book content across all subject disciplines. The first PDA was a six-month pilot launched in 2009 to test the feasibility of PDA as an e-book acquisitions method. Almost 5,000 e-book records were loaded into the Smathers Libraries' online catalog and made accessible to users. During the six months of the PDA project, users accessed the e-books 912 times, resulting in 193 purchases across all subject disciplines. Additionally, a usage report was generated months after the pilot ended that revealed most of the 193 e-books purchased had been accessed again with a favorable average cost per use. ${ }^{23}$

Spurred by the success of the first PDA, a shared plan to acquire research-level e-book content across multiple subject disciplines was developed and run as a partnership between the libraries at UF and Florida State University (FSU). The plan ran for two years, and the PDA was judged very successful by many librarians and selectors from both institutions on the basis of the e-books accessed and acquired, the average purchase cost, and the average cost per use. ${ }^{24}$ This shared PDA was similar in most elements to the conventional single library PDA, but it had four distinguishing elements that are worth mention: (1) each library contributed an equal share of funds to a deposit account; (2) usage was combined and neutral so expenditures were split evenly; (3) the e-book records loaded into the catalogs linked to the MyiLibrary platform allowed users from one or both libraries to access e-books simultaneously; and (4) after a purchase was triggered by use each library owned a copy of the same e-book. The fact the shared plan offered unlimited concurrent use across both libraries was a factor in its ultimate demise, as eventually many academic publishers withdrew from participation to the point the libraries shut down the PDA.

\section{Method of the UF Cost-Usage Studies}

UF's cost-usage studies focused on perpetually owned e-books purchased through package deals, firm orders, or PDA plans. This study relied on publisher- or vendorsupplied usage statistics for purchased titles in the form of Microsoft Excel spreadsheets. When available, COUNTER (Counting Online Usage of Networked Electronic Resources)-compliant reports were used in the analysis; however, COUNTER-compliant reports have their own limitations, for example, lack of subject- or call-number designations for each title. For this reason, the authors often relied on non-COUNTER-compliant reports. For the purposes of the study, an e-book use is defined on the basis of either COUNTER standards or the standards of a particular publisher or vendor. For all firm order and PDA analysis, MyiLibrary usage reports, which counted the number of "hits" (visits a title received), were consulted. The package analysis combined usage from the following publishers and vendors: Springer, Oxford, Rittenhouse, and Morgan and Claypool's Synthesis collections. All reports used in analyzing packages described usage as the number of successful full-text section or chapter requests. While these differences in defining use pose limitations on the ability to truly compare the cost and usage of various acquisitions methods, they do not eliminate the effectiveness of the study entirely. In many ways, these differences highlight the inconsistencies found between e-book providers that librarians must attempt to reconcile and strengthen the call for more robust, standardized publisher- or vendor-supplied usage reports.

Calculating cost and usage as comparisons across the three acquisitions methods was equally problematic. Cost per use was determined by taking the average price of an e-book purchased in the package and dividing it by the usage for each title, although many were not used. For e-books purchased using firm orders or through the PDA plans, the final cost of each title was available in the Coutts reports, so average cost and average cost per use were accurate. In this study, costs and cost usage for e-books received through publisher packages is based on an average, so direct comparisons to cost and cost usage to e-books purchased on firm ordering or via PDA plans can only be close approximations.

To analyze e-book cost and usage across acquisition methods and subject areas, usage statistics were aggregated from multiple e-book providers and their platforms. Cost and usage statistics for e-books purchased in packages from four publishers during 2009 to 2012 were downloaded from platforms or received directly from the publishers. For e-books purchased by firm orders (in 2010-12) and acquired as triggered purchases from the two PDA plans previously cited, reports were downloaded from Coutts' MyiLibrary platform and OASIS database. In all cases, the cost and usage figures for the three acquisitions methods were loaded into Excel spreadsheets, compiled, and sorted. For expediency and clarity, cost and usage statistics gathered in 2013 for e-books purchased via the two PDAs were combined into one table.

For e-books purchased in packages, cost and usage statistics were gathered from the following publisher sites: Springer's SpringerLink platform, Oxford Handbooks Online, Rittenhouse's R2 Digital Library, and Morgan and Claypool's Synthesis collections. Unfortunately, cost and usage figures for individual titles were not available for the e-books purchased in these publisher packages at the time of this study. Instead of sorting the titles by LC subject 
Table 1. Cost-Use of E-books Purchased in Packages by Subject Area

\begin{tabular}{|c|c|c|c|c|c|c|c|c|}
\hline Subject Area & Expenditures & $\begin{array}{c}\% \text { of } \\
\text { Expenditures }\end{array}$ & $\begin{array}{c}\text { No. of } \\
\text { E-books } \\
\text { Purchased* }\end{array}$ & $\begin{array}{c}\% \text { of } \\
\text { E-books } \\
\text { Purchased }\end{array}$ & $\begin{array}{c}\text { Avg. Cost } \\
\text { per E-book }\end{array}$ & Total Uses & $\begin{array}{l}\% \text { of Total } \\
\text { Uses }\end{array}$ & $\begin{array}{l}\text { Avg. Cos } \\
\text { per Use }\end{array}$ \\
\hline $\begin{array}{l}\text { Humanities/Social } \\
\text { Sciences }\end{array}$ & $\$ 54,701.09$ & 14.30 & 2,218 & 16.43 & $\$ 24.66$ & 13,270 & 11.77 & $\$ 4.12$ \\
\hline STEM & $\$ 262,755.73$ & 68.69 & 9,938 & 73.60 & $\$ 26.44$ & 72,774 & 64.55 & $\$ 3.61$ \\
\hline Medicine & $\$ 65,079.52$ & 17.01 & 1,346 & 9.97 & $\$ 48.35$ & 26,704 & 23.68 & $\$ 2.44$ \\
\hline
\end{tabular}

* Includes Synthesis package e-books

Table 2. Cost-Use and Non-use of E-books Purchased in Packages by Subject Area

\begin{tabular}{|c|c|c|c|c|c|c|c|}
\hline Subject Area & $\begin{array}{c}\text { No. of } \\
\text { E-books } \\
\text { Purchased* }\end{array}$ & $\begin{array}{c}\text { No. of } \\
\text { E-books Used }\end{array}$ & $\begin{array}{c}\% \text { of E-books } \\
\text { Used }\end{array}$ & $\begin{array}{l}\text { No. of } \\
\text { E-books Not } \\
\text { Used }\end{array}$ & $\begin{array}{l}\% \text { of E-books } \\
\text { Not Used }\end{array}$ & $\begin{array}{c}\text { Expenditure } \\
\text { for E-books } \\
\text { Used }\end{array}$ & $\begin{array}{c}\text { Expenditure } \\
\text { for E-books } \\
\text { Not Used }\end{array}$ \\
\hline $\begin{array}{l}\text { Humanities/Social } \\
\text { Sciences }\end{array}$ & 2,218 & 1,037 & 46.75 & 1,181 & 53.25 & $\$ 27,327.37$ & $\$ 27,373.72$ \\
\hline STEM & 9,463 & 4,666 & 49.31 & 4,797 & 50.69 & $\$ 123,330.43$ & $\$ 117,525.30$ \\
\hline Medicine & 1,346 & 848 & 63.00 & 498 & 37.00 & $\$ 48,175.23$ & $\$ 16,904.29$ \\
\hline $\begin{array}{l}\text { Total }=\text { all subject } \\
\text { areas }\end{array}$ & 13,027 & 6,551 & 50.29 & 6,476 & 49.71 & $\$ 198,833.04$ & $\$ 161,803.30$ \\
\hline
\end{tabular}

Excludes Synthesis package e-books

classification, each e-book package was assigned one of the three broad subject areas. In some cases e-books were classed by the publisher's preassigned disciplines. While this method of subject assignment is broad and not specific by title, it offers a simple but effective overview of the primary subject areas being supported.

The cost and usage of e-book titles acquired by firm order or through the PDA programs were kept separate while organized using a similar method: the e-books were sorted by call numbers as found in the bibliographic records into subject disciplines using LCC. The e-books sorted by LC disciplines were organized into three broad subject areas defined by LCC: classes A-P and TR-Z were designated HSS; classes Q and S-TP were designated STEM; and class $\mathrm{R}$ was designated as MED. It was a matter of compiling and determining the number of e-books purchased, total usage, average cost per title, and average cost per use by these three subject areas.

\section{Results of the Cost-Usage Studies}

\section{E-Book Package Acquisitions}

Cost and usage statistics for all the e-books purchased through publisher packages were gathered, sorted, and compiled into two tables. Table 1 details the composite results of several large package purchases that were often acquired to support the disciplines. The STEM area shows the most purchased e-books $(9,938)$ compared to HSS $(2,218)$ and MED (1,346). The e-books acquired for STEM equated to 74 percent of the total number of e-books purchased $(13,502)$ with by far the highest expenditures $(\$ 262,756)$ compared to expenditures in HSS $(\$ 54,701)$ or MED $(\$ 65,080)$. With almost three-fourths of the e-books purchased in these packages, STEM titles also had the most uses $(72,774)$ and percentage of usage (65 percent). The average cost per use for STEM titles (\$3.61) was lower than average cost per use of HSS e-books $(\$ 4.12)$, but not lower than the average cost per use of MED e-books (\$2.44). Interestingly, MED had the highest average purchase price (\$48.35) compared to STEM (\$26.44) or HSS (\$24.66), which shows despite the higher cost, MED titles are actually the most cost-effective.

Table 2 shows that MED also had the highest percentage of e-books used from the purchased packages (63 percent) compared to STEM (49 percent) and HSS (47 percent). The negative component of package purchases is the number of e-books that went unused: 1,181 in HSS; 4,797 in STEM; and 498 in MED. At the time of the study, the unused e-books accounted for 6,476 of the 13,027 titles purchased in publisher packages. The libraries spent $\$ 382,536$ dollars on e-book packages in this four-year 
Table 3. Cost-Use of Firm Ordered E-books by Subject Areas

\begin{tabular}{|c|c|c|c|c|c|c|c|c|}
\hline Subject Area & Expenditures & $\begin{array}{c}\% \text { of } \\
\text { Expenditures }\end{array}$ & $\begin{array}{c}\text { No. of } \\
\text { E-books } \\
\text { Purchased }\end{array}$ & $\begin{array}{c}\% \text { of } \\
\text { E-books } \\
\text { Purchased }\end{array}$ & $\begin{array}{c}\text { Avg. Cost } \\
\text { per E-book }\end{array}$ & $\begin{array}{l}\text { Total Uses } \\
\text { of E-books } \\
\text { Purchased }\end{array}$ & $\begin{array}{l}\% \text { of Total } \\
\text { Uses }\end{array}$ & $\begin{array}{l}\text { Avg. Cost } \\
\text { per Use }\end{array}$ \\
\hline $\begin{array}{l}\text { Humanities/Social } \\
\text { Sciences }\end{array}$ & $\$ 80,170.33$ & 64.05 & 1,011 & 71.45 & $\$ 79.30$ & 3,484 & 61.83 & $\$ 23.01$ \\
\hline STEM & $\$ 25,640.69$ & 20.49 & 211 & 14.91 & $\$ 121.52$ & 1,043 & 18.51 & $\$ 24.58$ \\
\hline Medicine & $\$ 19,350.12$ & 15.46 & 193 & 13.64 & $\$ 100.26$ & 1,108 & 19.66 & $\$ 17.46$ \\
\hline $\begin{array}{l}\text { Total }=\text { all subject } \\
\text { areas }\end{array}$ & $\$ 125,161.14$ & 100.00 & 1,415 & 100.00 & $\$ 88.45$ & 5,635 & 100.00 & $\$ 22.21$ \\
\hline
\end{tabular}

Table 4. Cost-Use and Non-use of Firm Ordered E-books by Subject Area

\begin{tabular}{lcccccc}
\hline & $\begin{array}{c}\text { No. of E-books } \\
\text { Used }\end{array}$ & $\begin{array}{c}\text { No. of E-books } \\
\text { Not Used }\end{array}$ & $\begin{array}{c}\text { Cost of } \\
\text { E-books Used }\end{array}$ & $\begin{array}{c}\text { Cost of } \\
\text { E-books } \\
\text { Unused }\end{array}$ & $\begin{array}{c}\% \text { of E-books } \\
\text { Used }\end{array}$ & $\begin{array}{c}\text { \% of E-books } \\
\text { Not Used }\end{array}$ \\
$\begin{array}{l}\text { Subject Area } \\
\begin{array}{l}\text { Humanities/Social } \\
\text { Sciences }\end{array}\end{array}$ & 452 & 559 & $\$ 36,471.69$ & $\$ 43,698.64$ & 44.71 & 55.29 \\
STEM & 120 & 91 & $\$ 14,976.68$ & $\$ 10,664.01$ & 56.87 & 43.13 \\
Medicine & 162 & 31 & $\$ 16,790.79$ & $\$ 2,559.33$ & 83.94 & 16.06 \\
Total = all subject areas & 734 & 681 & $\$ 68,239.16$ & $\$ 56,921.98$ & 51.87 & 48.13 \\
\hline
\end{tabular}

period, and consequently the libraries spent a substantial amount of funds on thousands of e-books that went unused.

\section{Firm Order Acquisitions}

A summary of cost and usage statistics for e-books firm ordered at UF in 2010-12 were sorted by LCC into three broad subject areas and recorded in two tables (see tables 3 and 4). Table 3 shows that during the three-year period, 1,415 e-books were acquired through firm orders with a total cost of $\$ 125,161$. HSS disciplines were the primary subject areas targeted for e-book firm ordering, with 1,011 e-books purchased for $\$ 80,170$, accounting for the greater percentage of the total expenditures (64 percent) and titles received (71 percent). The predominance in acquisition of titles and fund expenditures for the HSS subject area can be attributed to several factors: (1) HSS selectors outnumber the librarians who do firm order selection in STEM and MED; (2) HSS selectors are also allocated the most funds for firm ordering, as STEM and MED selectors elect to spend their aggregate funding on databases and e-journals that are of a higher priority to their clientele; and (3) the average cost of a HSS e-book ( $\$ 79$ per title) is much lower than the average cost of a STEM e-book (\$122 per title) or an e-book in MED (\$100 per title), so HSS funds stretched further. With more funds to spend and lower pricing, it is understandable that a significant percentage of firm-ordered e-books fell into the HSS subject area. As the bulk of firm orders occurred in the
HSS disciplines, it follows that the total number of uses for the e-books in HSS $(3,484)$ was much higher than e-books purchased in STEM $(1,043)$ or MED $(1,108)$. However, MED had the lowest percentage of expenditures (15 percent) for the three subject areas, yet had the best average cost per use (\$17) compared to HSS (\$23) or STEM (\$25). Despite the Health Science Center Libraries (HSCL) at UF having a very limited budget to purchase e-books through firm orders, the study revealed a healthy cost benefit for the money spent on e-books in MED. The high cost-use ratio for MED e-books is explained by HSCL firm ordering practices that are discriminate and usually in response to requests from faculty and researchers.

Table 4 shows that MED had the highest percentage of firm-ordered e-books that were actually used by patrons (162 of 193 e-books purchased = 84 percent) when compared to STEM disciplines (120 of 211 e-books purchased $=57$ percent) or HSS disciplines (452 of 1,011 e-books purchased $=45$ percent). The fact that almost half of the e-books purchased in the STEM disciplines and more than half of the e-books firm ordered in the HSS disciplines were unused is troubling because it suggests e-books individually selected for purchase might have the same circulation issues associated with individually selected print books in academic libraries. Over the three years, $\$ 56,922$ was spent on individually selected e-books that were not used at the time of the study, which is not a pattern of cost value for a library facing restrictive material budgets. 
Table 5. Cost-Use of PDA Purchased E-books by Subject Area

\begin{tabular}{|c|c|c|c|c|c|c|c|c|}
\hline Subject Areas & Expenditures & $\begin{array}{c}\% \text { of } \\
\text { Expenditures }\end{array}$ & $\begin{array}{c}\text { No. of } \\
\text { E-books } \\
\text { Purchased }\end{array}$ & $\begin{array}{c}\% \text { of } \\
\text { E-books } \\
\text { Purchased }\end{array}$ & $\begin{array}{c}\text { Avg. Cost } \\
\text { per E-book }\end{array}$ & $\begin{array}{l}\text { Total Uses } \\
\text { of E-books } \\
\text { Purchased }\end{array}$ & $\begin{array}{c}\% \text { of Total } \\
\text { Use }\end{array}$ & $\begin{array}{l}\text { Avg. Cost } \\
\text { per Use }\end{array}$ \\
\hline $\begin{array}{l}\text { Humanities/Social } \\
\text { Sciences }\end{array}$ & $\$ 42,857.35$ & 61.76 & 363 & 64.36 & $\$ 118.06$ & 4,971 & 63.60 & $\$ 8.62$ \\
\hline STEM & $\$ 16,461.47$ & 23.72 & 123 & 21.81 & $\$ 133.83$ & 2,074 & 26.54 & $\$ 7.94$ \\
\hline Medicine & $\$ 10,076.79$ & 14.52 & 78 & 13.83 & $\$ 129.19$ & 771 & 9.86 & $\$ 13.07$ \\
\hline $\begin{array}{l}\text { Total }=\text { all subject } \\
\text { areas }\end{array}$ & $\$ 69,395.61$ & 100.00 & 564 & 100.00 & $\$ 123.04$ & 7,816 & 100.00 & $\$ 8.88$ \\
\hline
\end{tabular}

Patron-Driven Acquisitions

Cost-usage figures were gathered from the two Ingram Content Group patron-driven acquisitions plans run at UF and compiled into table 5. Of the 564 e-books purchased during the two PDAs, 363 of the titles were classified as HSS (64 percent), 123 of the titles were classified as STEM (22 percent), and 78 of the titles purchased were classified as MED (14 percent). The total expenditures and percentages of spending have an almost identical breakdown across the three subject areas because the cost of the e-books purchased in HSS amounted to $\$ 42,857$ (62 percent of the total) while STEM amounted to $\$ 16,461$ (24 percent) and MED amounted to $\$ 10,077$ (15 percent). Usage statistics follow a similar pattern, with 4,971 uses occurring in HSS (64 percent) compared to 2,074 uses in STEM (27 percent) and 771 uses in MED (10 percent). The propensity of titles purchased, costs, and usage for HSS e-books can be explained by the fact that approximately the same percentage of e-book discovery records loaded into the OPAC were classified in HSS disciplines (65 percent). Not surprisingly, with almost two-thirds the number of e-book records available in the OPAC for users to access, the final cost-usage statistics of the two PDA plans would be HSS dominated.

Despite more HSS classified e-books being made available, used, and purchased through the PDA plans, STEM had the most efficient average cost per use $(\$ 7.94)$ compared to HSS (\$8.62) or MED (\$13.07). MED by far is the subject area that benefits least from the two PDA plans, with the fewest number of titles purchased, least amount of uses, and highest cost per use. These statistics seem to indicate that PDA plans designed to offer content across all disciplines are more likely to be HSS-centric; and perhaps publishers of e-books in medicine-and to an extent publishers in the science and engineering fields - do not offer all or their most-desired content through PDA. Future studies to investigate how STEM and MED e-book content is or is not made available by some publishers for PDA plans, and the effect this has on collection endeavors in academic and medical libraries, would seemingly be a logical and productive area of research.
Comparing Cost-Usage across Acquisitions Methods

Comparing the compiled cost-usage statistics of the three methods of acquisition across the three broad subject areas reveals several interesting facets. The average cost of an e-book purchased through packages is by far the lowest (\$28.33 per title; see table 1) compared to e-books purchased by firm orders ( $\$ 88.45$ per title; see table 3 ) or from PDAs (\$123.04 per title; see table 5 ). This notable average cost disparity is perhaps because of the discounts publishers offer for package deals. Yet the fact that all the e-books purchased through PDA are used and many of the e-books purchased by firm orders or in packages go unused certainly balances the lower average cost for e-books acquired on PDA.

In general, all three acquisitions methods reflect solid total usage: the 1,415 e-books purchased through firm orders had 734 uses (see tables 3 and 4); the 564 e-books purchased through the PDA plans had 7,816 uses (see table 5); and the 13,502 e-books purchased in packages (that were used) had 112,748 uses (see table 1). Most telling is the comparison of the average cost per use from the three acquisitions methods because it demonstrates a wide range of results. The average cost per use of e-books purchased through firm orders is $\$ 22.21$ (see table 3), for e-books purchased through the PDA plans it is $\$ 8.88$ (see table 5), and for e-books purchased in packages it is $\$ 3.39$ (see table 1). While the lowest (and best) cost per use is for the e-books purchased in packages, the fact that almost half of the e-books were never used is disconcerting.

\section{Comparing Composite Cost Usage by Subject Areas}

Table 6 shows a composite summary of cost-use of the three acquisitions methods, sorted into the three broad subject areas. The Smathers Libraries spent the most funds on STEM e-books $(\$ 304,858)$ representing slightly more than half (53 percent) of the total amount spent $(\$ 573,493)$. STEM disciplines also showed the most e-books purchased $(10,272)$, the most usage $(75,891)$, the lowest average cost (\$29.68), and an excellent cost per use (\$4.02). This dominance in expenditures, e-books purchased, and usage can be 


\begin{tabular}{lccccccc}
\hline \multicolumn{1}{l}{ Table 6. E-books Purchased Firm Order-PDA-Package Composite by Subject Area } \\
\hline
\end{tabular}

explained by the fact that STEM disciplines were the recipients of large, often expensive package purchases.

HSS disciplines had the second most funding spent on e-books $(\$ 177,729)$, and had the second highest number of e-books purchases $(3,592)$, yet the HSS e-books had the least amount of uses $(21,725)$ equating to a mere 17 percent of the total usage. HSS e-books also had the highest cost per use (\$8.18) of the three disciplines. These figures can be attributed to many of the e-books purchased either by firm orders or through packages that went unused in the HSS disciplines, which might indicate that PDA is the acquisitions method best suited for HSS.

MED had by far the lowest amount funding spent on e-books $(\$ 90,906)$ of the three broad subject areas and fewest e-books purchased $(1,617)$, accounting for a little more than 10 percent of the total e-books purchased $(15,481)$. Much of this can be attributed to the UF Health Science Center Libraries having smaller budgets for e-books in general, with most of their e-books acquired in costly packages. Despite the low funds expended and number of e-books purchased, MED had the second highest usage $(28,583)$. Also, despite the highest cost per title of all the subject areas for e-books purchased on PDA, the MED titles still had the best combined cost per use (\$3.18) figure.

\section{Effect on Collection Development and Budgeting}

At the Smathers Libraries, an important strategic objective has been the crafting of new evidence-based budget and collection management policies. The findings of this project are proving to be helpful in planning future strategies. At the beginning of fiscal year 2013-14, steps were taken to reallocate and better utilize e-book budgets in part because of the cost-usage data gathered during this project. These steps are summarized below:

1. For the HSS disciplines, e-books purchased by package or firm ordered revealed a high percentage (approximately 50 percent) of nonuse while the e-books acquired from the PDA plans in the HSS areas show a robust average cost per use. Given that workflow for firm ordering involves a lot of selector and staff time to select, order, and purchase each e-book individually, the number of unused e-books would indicate that PDA seems the more efficient method for acquiring e-books in HSS disciplines. However, it was also determined that a minimum level of firm-ordered e-books was essential because often the individually ordered e-books are in response to faculty and researcher requests-in a sense "patrondriven"-so firm-order budgets were reduced, not eliminated. This resulted in a significant portion of the e-books budgets used in the past for firm orders in the HSS subject areas being transferred and used for e-book PDA and package purchases.

2. For the STEM disciplines, the vast usage of e-books is revealing about the value of the e-book format for STEM users, but equally important is the relatively low average cost per title (\$26.44) and excellent average cost per use $(\$ 3.61)$ for e-books purchased in publisher packages. Despite the significant numbers of unused e-books that were acquired in package purchases, the cost-use statistics for STEM e-books show this to be a valid method of acquisitions. It is also recognized that purchasing e-books packages requires much lower overhead in staff time and maintenance because selection is at the collection level, there is a single invoice, and records are batch loaded. The result is that e-book budgets for individual firm orders in the science disciplines were batched by selectors in the Marston Science Library and used to purchase a large e-book package.

3. For the MED disciplines, funding for package purchases is often derived from one-time or carryforward types of windfall budgets, but since a high percentage of e-books received through package purchases are used (63 percent), and many are used heavily with an excellent final average cost per use (\$2.44), these figures indicate that MED truly benefits from these package deals. Individual e-book firm orders also revealed a high percentage of use and were very cost-effective, but with a relatively small budget, firm 
ordering for e-books in MED is not a viable option. As a result, the findings indicate that the UF Health Science Center Libraries had been on the right track in limiting individual firm orders for e-books while using carry-forward or one-time funding to purchase large e-book packages.

The findings of this cost-usage project legitimized the PDA model for acquiring e-books, especially for HSS disciplines. Earlier studies conducted at the Smathers Libraries had indicated that e-books acquired through PDA plans require less staff time and overhead to manage than e-books purchased through firm ordering. In addition, the administration and librarians at UF are staunch supporters of the cost-effectiveness of PDA because e-books are purchased are used. However, there was a legitimate concern that the two Coutts PDAs were not supporting the STEM and MED disciplines as strongly as the HSS subjects, so this problem was addressed with an alternative PDA plan. A good portion of material budgets used in the past for e-book firm ordering were channeled into the creation of several new PDA plans:

- One large PDA project is using existing profiles from the libraries' approval/slip plan established with Coutts to load MARC e-book records into the catalog, making the approval/slip plan "PDA-preferred."

- Noting the cost-usage of the two previous PDA plans with Coutts were HSS-dominant, the libraries established an e-books PDA with another aggregator (EBL) to supply content in the STEM and MED subject areas.

- To take advantage of the quality content and high use of e-books received through packages, and to offset the lost funds for unused titles, the Smathers Libraries have launched three evidence-based acquisitions (EBA) plans in the current fiscal year, two of them focusing on acquiring e-books for the STEM and MED disciplines. EBA plans are an appealing option as publishers will load packages of e-books into the library's catalog for use, but the library purchases only a certain percentage (the higher-use titles) of the package. The assumption is that EBA plans will retain the positive attributes of package purchases (high use, low maintenance) but will no longer require the Libraries to purchase large numbers of unused e-books as part of the agreement.

In addition to funding the number and type of PDA plans, the Smathers Libraries noted the value of purchasing small and large publisher package plans for specific subject areas, and the Libraries still support this mode of acquisitions. One-time funding received by the Libraries at the end of the past fiscal year was used to buy large publisher packages of e-books in STEM and MED, while other subjects disciplines (e.g., architecture) were supported in smaller scope.

\section{Conclusion}

The cost-usage research project conducted at the Smathers Libraries initially set three key objectives for what the data might reveal for e-books purchased by firm order, PDA, or packages, particularly across three broad subject areas. The first objective of the research project was "How does costuse of e-books purchased in packages, selected using firm orders, and acquired by PDA compare with regard to the methods of acquisitions?" The cost-use data reviewed during the project revealed that e-books purchased in the three acquisitions methods do have differences, and that each method has its place in the collection development strategies of the Smathers Libraries. Firm-ordered e-books may not be as cost-effective as e-books acquired through packages or PDA plans, but the e-books that do get accessed at least once often have significant usage.

The second objective of the project built on the first, "How does the cost-use of e-books as acquired using the three main acquisitions methods compare when sorted by three broad subject areas-humanities and social sciences (HSS); science, technology, engineering, and mathematics (STEM); and medicine (MED), which includes related health and physiology disciplines?" Again, data from the study showed that e-book usage sorted into the three broad subject areas support all disciplines, while cost-usage analyses indicate that e-books received on package purchases and PDA plans support certain subject areas more than others. While package purchases of e-books show effective costusage in the STEM and MED fields, the PDAs run on the Coutts' MyiLibrary platform support HSS disciplines more than STEM and MED. Such observations are proving to be useful for UF selectors and librarians in developing more informed acquisitions strategies.

Finally, the third objective of the project may have been the most important of all, "How will this study of cost-use analysis of e-books at UF affect collection development, particularly future e-book initiatives and budget allocation?" As summarized in the "Effect on Collection Development and Budgeting" section of this paper, the cost and usage data analyzed during the project are already affecting collection and budgeting endeavors at the Smathers Libraries. For example, the study showed a spotty cost-usage benefit for e-books purchased by firm orders, and the Smathers Libraries took steps to reallocate material budgets from the purchase of e-books by firm orders and use the funds for PDA and package purchases. Yet, because many of the firm ordered e-books are acquired from faculty and user requests (a type of PDA), the libraries are still allocating funds for 
these purchases, indicating firm ordering still has a role in collection development.

The research project showed that each of the three acquisitions methods have positive and negative attributes, and each has its role in collection development. The study provided statistical evidence to apply in the reallocation of budgets for e-book purchases made across subject areas and by varying acquisitions methods. Based on the cost-usage project results as described in this paper, the Smathers Libraries will continue to pilot and explore many patrondriven acquisitions models while making ongoing adjustments to budget allocations that are driven increasingly by evidence-based initiatives. Thus cost-usage and e-book user research needs to be ongoing and applicable when developing collection and budget strategies.

\section{References}

1. "Stats and Facts for Prospective Students," University of Florida, accessed July 28, 2014, www.admissions.ufl.edu/ufpro file.html.

2. "Colleges," University of Florida, accessed July 28, 2014, www.ufl.edu/academics/colleges.

3. Gail Herrera, "Deliver the eBooks Your Patrons and Selectors Both Want! PDA Program at the University of Mississippi," Serials Librarian 63, no. 2 (2012): 178-86, dx.doi.org/ 10.1080/0361526X.2012.700780.

4. Judith M. Nixon, Robert S. Freeman, and Suzanne M. Ward, Patron-Driven Acquisitions: Current Successes and Future Directions (New York: Routledge, 2011); David A. Swords, Patron-Driven Acquisitions: History and Best Practices (Boston: De Gruyter Saur, 2011).

5. Jodi Shepherd and Marc Langston, "Shared Patron Driven Acquisition of E-Books in the California State University Library Consortium," Library Collections, Acquisitions \& Technical Services 37, no. 1-2 (2013): 34-41, dx.doi .org/10.1016/j.lcats.2013.08.001.

6. Ibid., 37.

7. Kristine J. Anderson et al., "Liberal Arts Books on Demand: A Decade of Patron-Driven Collection Development, Part 1," Collection Management 35, no. 3 (2010): 125-41, dx.doi.org /10.1080/01462679.2010.486959; Marianne Stowell Bracke, Jean-Pierre V. M. Hérubel, and Suzanne M. Ward, "Some Thoughts on Opportunities for Collection Development Librarians," Collection Management 35, no. 3-4 (2010): 25559, dx.doi.org/10.1080/01462679.2010.486959.

8. Robert Alan et al., "Approval Plan Profile Assessment in Two Large ARL Libraries," Library Resources \& Technical Services 54, no. 2 (2010): 64-76, dx.doi.org/10.5860/lrts.54n2.64.

9. Susan Hinken and Emily J. McElroy, "Chapter 2: Consortial Purchasing of E-Books," Library Technology Reports 47, no.
8 (2011): 8-13, dx.doi.org/10.5860/ltr.47n8.

10. Leslie J. Reynolds et al., "User-Driven Acquisitions: Allowing Patron Requests to Drive Collection Development in an Academic Library," Collection Management 35, no. 3-4 (2010): 244-54, dx.doi.org/10.1080/01462679.2010.486992.

11. Steve Sharp and Sarah Thompson, "'Just in Case’ vs. 'Just in Time’: E-book Purchasing Models,” Serials 23, no. 3 (2010): 201-6, dx.doi.org/10.1629/23201.

12. Lisa Shen et al., "Head First into the Patron-Driven Acquisition Pool: A Comparison of Librarian Selections Versus Patron Purchases," Journal of Electronic Resources Librarianship 23, no. 3 (2011): 203-18, dx.doi.org/10.1080/194112 6X.2011.601224.

13. Nancy Sprague and Ben Hunter, “Assessing E-Books: Taking a Closer Look at E-Book Statistics," Library Collections, Acquisitions \& Technical Services 32, no. 3 (2008): 150-57, dx.doi.org/10.1016/j.lcats.2008.12.005.

14. Amy Hoseth and Merinda McLure, "Perspectives on E-Books from Instructors and Students in the Social Sciences," Reference \& User Services Quarterly 51, no. 3 (2012): 278-88, dx.doi.org/10.5860/rusq.51n3.278.

15. Merinda McLure and Amy Hoseth, "Patron-Driven E-book Use and Users' E-book Perceptions: A Snapshot," Collection Building 31, no. 4 (2012): 136-47, dx.doi .org/10.1108/01604951211274043.

16. Sarah Pomerantz, "The Availability of E-books: Examples of Nursing and Business," Collection Building 29, no. 1 (2010): 11-14, dx.doi.org/10.1108/01604951011015240.

17. Alain R. Lamothe, "Comparing Usage between Selective and Bundled E-Monograph Purchases," Collection Building 32, no. 3 (2013): 116-21, dx.doi.org/10.1108/CB-03-2013-006.

18. Mirela Roncevic, "Chapter 2: Criteria for Purchasing E-Book Platforms," Library Technology Reports 49, no. 3 (2013): 10-13, dx.doi.org/10.5860/ltr.49n3.

19. Amber Lannon and Dawn McKinnon, "Business E-books: What Can Be Learned from Vendor Supplied Statistics?" Journal of Business \& Finance Librarianship 18, no. 2 (2013): 89-99, dx.doi.org/10.1080/08963568.2013.767121.

20. James Cory Tucker, "Ebook Collection Analysis: Subject and Publisher Trends," Collection Building 31, no. 2 (2012): 40-47, dx.doi.org/10.1108/01604951211229836.

21. Ibid., 42 .

22. As reported by the University of Florida for ARL Statistics (2012-2013), http://publications.arl.org/ARL-Statistics -2012-2013.

23. Steven Carrico and Michelle Leonard, "Patron-Driven Acquisitions and Collection Building Initiatives at the University of Florida," Florida Libraries 54, no. 1 (Spring 2011): 14-17.

24. Steven Carrico, Trey Shelton, and Roy Ziegler, "The FSU-UF Patron-Driven Acquisitions Plan: A Cutting Edge Collaboration," Florida Libraries 56, no. 1 (Spring 2013): 18-23. 